\title{
Suplementasi Mineral Cu dan Zn dalam Pakan terhadap Organ Dalam dan Lemak Abdomen Ayam Broiler
}

Effect of Supplementation of Copper and Zinc in Feed on Giblets and Abdominal Fat of Broilers

R Lestari, A Darmawan, I Wijayanti*

Corresponding email:

wijayanti@apps.ipb.ac.id

Departemen Ilmu Nutrisi dan Teknologi Pakan, Fakultas Peternakan, Institut Pertanian Bogor (Bogor Agricultural University/IPB University)

\section{ABSTRACT}

This experiment was design to evaluate the effects of supplementation of $\mathrm{Zn}$ and $\mathrm{Cu}$ in inorganic or organic form on broiler's percentage of giblets and abdominal fat of 35 day-old broiler chickens. The experiment used a completely randomized design with two treatments, 17 replicates and 32 birds per pen (816 female and 272 male). The treatments based on the type of mineral i.e. inorganic (T1) and organic (T2). The types of mineral did not affected the weight and percentage of weight of bursa fabricius, lymph, heart, bile gland, kidney, and abdominal fat. The types of mineral did not affected the weight of thymus, liver, proventriculus, pancreas, and gizzard, but were affected their percentage of weight $(\mathrm{p}<0.05)$. The types of mineral were affected the length and percentage of weight of duodenum, jejunum,and ileum $(\mathrm{p}<0.05)$. The types of mineral were affected the length of secca, but did not affected its percentage of weight $(\mathrm{p}<0.05)$. The types of mineral did not affected the length of colon, but were affected its percentage of weight $(\mathrm{p}<0.05)$. The supplementation of mineral $\mathrm{Cu}$ and $\mathrm{Zn}$ in organic form has better absorption of nutrient and positive effect to health of chickens in stress due to heat stress.

Key words: broiler, copper, inorganik mineral, organik mineral, zinc

\section{ABSTRAK}

Percobaan ini dirancang untuk mengevaluasi suplementasi $\mathrm{Zn}$ dan $\mathrm{Cu}$ dalam bentuk inorganik dan organik terhadap persentase organ dalam dan lemak abdomen ayam broiler yang berumur 35 hari. Rancangan percobaan yang digunakan yaitu Rancangan Acak Lengkap (RAL) dengan 816 betina dan 272 jantan dengan 2 perlakuan dan 17 ulangan. Perlakuan T1 dengan suplementasi mineral $\mathrm{Cu}$ dan $\mathrm{Zn}$ inorganik, dan perlakuan T2dengan suplementasi mineral $\mathrm{Cu}$ dan $\mathrm{Zn}$ organik. Suplementasi yang diberikan yaitu T1 masing-masing 150 ppm Cu dan 100 ppm ZnSO4 pada semua fase untuk mineral inorganik, sedangkan broiler yang diberi perlakuan T2 disuplementasi masing-masing 200 ppm, 150 ppm, 75 ppm Cu (basic copper chloride pada fase Starter, pre Starter, grower-finisher dan 80 ppm ( $\mathrm{ZnOHCl})$ untuk mineral organik. Suplementasi mineral organik $\mathrm{Cu}$ dan $\mathrm{Zn}$ meningkatkan persentase bobot organ timus, pankreas, gizzard, panjang relatif dan persentase bobot duodenum, jejunum, dan kolon, serta menurunkan persentase bobot hati dan proventrikulus.

Kata kunci: broiler, mineral inorganic, mineral organik, seng, tembaga 


\section{PENDAHULUAN}

Ayam broiler yang umumnya dibudidayakan oleh peternak memiliki laju pertumbuhan yang cepat sehingga membutuhkan suhu lingkungan pemeliharaan yang ideal. Laju pertumbuhan yang cepat ini memberikan dampak terhadap laju metabolisme yang tinggi sehingga diperlukan penambahan feed supplement dan pengkondisian suhu kandang untuk mengurangi cekaman panas pada kondisi lingkungan tropis seperti Indonesia. Metode pengkondisian suhu kandang sangat sulit diterapkan di Indonesia karena sebagian besar peternak di Indonesia masih menggunakan tipe kandang sistem terbuka. Sistem kandang terbuka ini terkadang merugikan peternak dikarenakan laju pertumbuhan ayam tidak optimal dan jika menggunakan sistem kandang tertutup memerlukan investasi yang sangat mahal. Penambahan feed supplement berupa antioksidan masih menjadi solusi alternatif untuk menurunkan cekaman panas akibat laju metabolisme yang tinggi pada ayam broiler.

Penambahan antioksidan di dalam pakan ayam broiler (feed supplement) dapat berupa penambahan mineral mikro seperti Zinc (Zn) dan Copper (Cu). Mineral mikro merupakan kofaktor dan katalis dalam sistem enzim, selain itu berperan dalam dalam sistem imun dan sekresi hormon (Dieck et al. 2003). Zinc adalah mineral mikro yang essensial untuk makhluk hidup dan berperan di beberapa jalur metabolisme. Zinc merupakan kofaktor lebih dari 300 enzim di sistem metabolisme (Bun et al. 2011). Zinc juga memiliki fungsi penting dalam sistem pertahanan antioksidan (Powel 2000). Sedangkan $\mathrm{Cu}$ adalah salah satu mineral mikro yang sangat penting untuk laju pertumbuhan, perkembangan dan fungsi dari organ makhluk hidup. $\mathrm{Cu}$ memiliki kemampuan mudah untuk menerima dan memberikan elektron sehingga $\mathrm{Cu}$ banyak terlibat dalam proses biokimia (Maltais et al. 2013). Cu merupakan bagian aktif dari banyak enzim termasuk cooper-zinc superoxide dismutase (CuZnSOD), cytochrome c-superoxide, L-lysine oxidase, ascorbate oxidasei, tyrosinase, dan dopamine betahydroxylase (Gaetke \& Chow 2003). Enzim-enzim tersebut memiliki peran yang sangat penting sebagai antioksidan, sintesis melamin, pembentukkan jaringan ikat, metabolisme dopamin, dan respirasi mitokondria (Maltais et al. 2013). Pada umumnya, penambahan mineral mikro diberikan dalam bentuk inorganik di dalam ransum broiler sesuai dengan kebutuhan broiler, namun mineral inorganik dapat mengalami kehilangan dalam jumlah yang besar karena sifat dari antagonistik pakan, yang menyebabkan penurunan bioavailabilitasnya secara signifikan (Aksu et al. 2012). Kelemahan ini menyebabkan banyak pabrik pakan menambahkan mineral mikro inorganik dalam dosis yang melebihi dosis dari kebutuhan broiler (Swiatkiewicz et al. 2014).

Pemberian mineral mikro inorganik yang berlebih secara terus menerus di dalam ransum broiler akan menyebabkan pencemaran lingkungan dari hasil akumulasi mineral pada feses broiler (Bao \& Choct 2009). Oleh karena itu, penggunaan mineral mikro organik telah disarankan untuk digunakan di dalam ransum broiler karena memiliki nilai bioavalabilitas yang lebih tinggi sehingga penggunaan di ransum broiler menjadi lebih efisien dan tidak mencemari lingkungan (Aksu et al. 2012). Bioavailabilitas pada mineral organik mencapai 64\% lebih tinggi dibanding mineral inorganik dalam bentuk sulfat (Star et al. 2012)

Pengaruh mineral $\mathrm{Zn}$ dan $\mathrm{Cu}$ baik dalam bentuk organik dan inorganik pada ayam broiler sudah banyak dilakukan oleh para ahli. Menurut Abdallah et al. (2009), ayam yang diberikan pakan dengan suplementasi $100 \%$ mineral mikro organik memiliki performa dan konversi pakan yang lebih baik dibandingkan dengan ayam yang diberikan suplementasi 100\% inorganik. Menurut Sirri et al. (2016), ayam yang diberikan suplementasi mineral $\mathrm{Zn}$ dan $\mathrm{Cu}$ organik memiliki bobot yang lebih tinggi, konversi pakan yang lebih baik, memiliki daya tahan tubuh yang lebih baik dibandingkan mineral $\mathrm{Zn}$ dan $\mathrm{Cu}$ inorganik. Performa produksi ayam broiler yang baik dipengaruhi oleh organ dalam yang merupakan pusat terjadinya proses metabolisme di dalam tubuh ayam broiler. Penelitian ini berfokus untuk mengamati pengaruh mineral organik $\mathrm{Zn}$ dan $\mathrm{Cu}$ dalam bentuk organik dan inorganik terhadap organ dalam serta lemak abdomen pada ayam broiler.

\section{METODE}

\section{Ternak dan Ransum Percobaan}

Ternak yang digunakan pada penelitian ini adalah day old chick (DOC) ayam broiler strain Cobb dengan jenis kelamin betina sebanyak 816 ekor dan jantan sebanyak 272 ekor. DOC diperoleh dari PT Bibit Unggul Prima Sejati. Ayam broiler diberikan ransum dengan formula yang berbeda tergantung fase ayam broiler tersebut (preStarter, Starter, grower, dan finisher) selama 5 minggu. Formula yang digunakan pada penelitian ini disajikan pada Tabel 1.

Ayam broiler hari ke 1 hingga 10 diberikan ransum preStarter, ayam broiler hari ke 11 diberikan ransum $25 \%$ preStarter dan $75 \%$ Starter sebagai masa peralihan, ayam broiler hari ke 12 hingga 21 diberikan ransum Starter, dan ayam broiler hari ke 22 hingga 35 diberikan ransum grower-finisher. 
Tabel 1 Formula ransum dan komposisi nutrien ransum penelitian

\begin{tabular}{|c|c|c|c|}
\hline Bahan Pakan & $\begin{array}{l}\text { Pre- } \\
\text { Starter }\end{array}$ & Starter & $\begin{array}{l}\text { Grower- } \\
\text { Finisher }\end{array}$ \\
\hline Jagung & 47,96 & 60,71 & 54,90 \\
\hline Bungkil kedelai Argentina & 31,71 & 29,53 & 25,55 \\
\hline Pollard gandum & 7,95 & - & 10,00 \\
\hline Minyak kelapa sawit & 3,80 & 2,41 & 3,31 \\
\hline CGM & 2,61 & 1,54 & 2,08 \\
\hline Tepung ikan lokal & 1,50 & 1,00 & 1,00 \\
\hline Dedak & 1,00 & 1,50 & - \\
\hline Bubuk limestone & 0,97 & 0,88 & 0,86 \\
\hline $\mathrm{DCP}$ & 0,93 & 0,94 & 0,67 \\
\hline Garam & 0,19 & 0,18 & 0,14 \\
\hline Sodium bikarbonat & 0,03 & 0,08 & 0,32 \\
\hline Lysine & 0,19 & 0,13 & 0,12 \\
\hline DL-Methionine & 0,27 & 0,24 & 0,19 \\
\hline Choline Chloride & 0,26 & 0,25 & 0,25 \\
\hline L-Threonine & 0,05 & 0,02 & 0,03 \\
\hline Mineral Premix & 0,25 & 0,25 & 0,25 \\
\hline Mix Trouwvit & 0,10 & 0,10 & 0,10 \\
\hline Toxo MX & 0,15 & 0,15 & 0,15 \\
\hline Fylax Powder & 0,05 & 0,05 & 0,05 \\
\hline TNOX Antioxidant & 0,03 & 0,03 & 0,03 \\
\hline Quantum Blue & 0,01 & 0,01 & 0,01 \\
\hline Total & 100 & 100 & 100 \\
\hline \multicolumn{4}{|l|}{$\begin{array}{l}\text { Kandungan Nutrien } \\
\text { Pakan }\end{array}$} \\
\hline Bahan Kering (\%) & 88,72 & 88,44 & 88,45 \\
\hline ME (kkal/kg) & 3008,00 & 3086,00 & 3167,00 \\
\hline Protein Kasar (\%) & 22,00 & 20,00 & 19,00 \\
\hline Lemak kasar (\%) & 6,08 & 4,79 & 5,45 \\
\hline Serat kasar (\%) & 3,19 & 2,32 & 2,10 \\
\hline Abu (\%) & 5,71 & 5,22 & 4,57 \\
\hline Kalsium (\%) & 0,90 & 0,84 & 0,76 \\
\hline Phospor tersedia (\%) & 0,45 & 0,42 & 0,38 \\
\hline Lysine (\%) & 1,29 & 1,14 & 1,04 \\
\hline Methionine (\%) & 0,61 & 0,55 & 0,50 \\
\hline
\end{tabular}

\section{Kandang dan Peralatan}

Kandang yang digunakan adalah kandang dengan ukuran $2 \mathrm{~m} \times 1 \mathrm{~m}$ yang diberi alas litter sekam padi dengan kepadatan 32 ekor per pen. Setiap pen dilengkapi dengan 2 tempat pakan, 2 tempat minum, dan 3 lampu pijar 100W sebagai pemanas buatan. Alat pendukung lainnya berupa timbangan digital, hygrothermometer, kipas, dan pisau potong.

\section{Prosedur Penelitian}

\section{Pemeliharaan Ayam Broiler}

Sebelum penelitian dimulai, kandang disapu dan dibersihkan dengan menggunakan detergen serta diberikan disinfektan. Setelah bersih, semua peralatan kandang disusun rapi. Day old chick (DOC) yang baru tiba langsung ditimbang untuk mengetahui bobot awalnya lalu diberikan larutan gula 10\% untuk menggantikan energi DOC yang hilang selama perjalanan. Metode sexing dilakukan dengan mengamati pertumbuhan bulu sayap primer dengan DOC betina memiliki bulu sayap primer yang lebih panjang dibandingkan bulu penutup,
Tabel 2 Kadar mineral Zn dan Cu dalam bentuk inorganik dan organik

\begin{tabular}{|c|c|c|c|c|c|c|c|}
\hline \multirow[b]{2}{*}{ Perlakuan } & \multirow[b]{2}{*}{ n Sumber } & \multicolumn{3}{|c|}{$\mathrm{Cu}(\mathrm{ppm})$} & \multirow{2}{*}{$\begin{array}{l}\mathrm{ZnSO}_{4} \\
(\mathrm{ppm})\end{array}$} & \multirow{2}{*}{$\begin{array}{c}\text { IBZ } \\
\text { (ppm) }\end{array}$} & \multirow{2}{*}{$\begin{array}{c}\mathrm{MnSO}_{4} \\
(\mathrm{ppm})\end{array}$} \\
\hline & & $\begin{array}{c}\text { Pre- } \\
\text { Starter }\end{array}$ & Starter & $\begin{array}{l}\text { Grower- } \\
\text { Finisher }\end{array}$ & & & \\
\hline T1 & Sulfat & 150 & 150 & 150 & 100 & - & 80 \\
\hline $\mathrm{T} 2$ & IntelliBond & 200 & 150 & 75 & - & 80 & - \\
\hline
\end{tabular}

sedangkan DOC jantan memiliki bulu saya primer yang sama panjangnya dengan bulu penutup. DOC tersebut dikelompokkan di dalam kandang dengan rasio jantan:betina sebesar 1:3.

Ayam broiler tersebut dibagi menjadi 2 perlakuan dan 17 ulangan yang dipelihara di 34 pen (masingmasing 32 ekor). Jadwal pemberian pakan dan air sehari 2 kali yaitu jam 06.00 WIB dan 16.00 WIB. Suhu dan kelembaban dicatat 3 kali sehari (07.00 WIB, 13.00 WIB, dan 17.00 WIB) dengan menggunakan hygrothermometer digital. Penimbangan bobot badan dan sisa pakan dilakukan setiap minggu sehingga diperoleh data pertumbuhan bobot badan harian.

\section{Pengambilan Sampel Organ Dalam}

Seratus dua ekor ayam (masing-masing 3 ekor yaitu 1 jantan dan 2 betina) yang sudah berumur 35 hari menjadi sampel untuk pengamatan organ dalam. Ayam terlebih dahulu ditimbang bobot hidup sebelum dipotong. Pemotongan dilakukan pada bagian leher dengan cara memotong bagian esofagus, pembuluh darah vena jugularis, trakea, dan arteri karotidae. Bulu ayam dicabut secara manual dan dilanjutkan dengan pengambilan sampel organ dalam. Organ imunitas yang diamati adalah thymus, limfa, dan bursa fabricius, sedangkan organ pencernaan dan organ dalam lain yang diamati adalah proventrikulus, gizzards, hati, empedu, limfa, ginjal, jantung, pankreas, duodenum, jejenum, ileum, sekum, dan kolon. Khusus untuk usus (duodenum, ileum, jejenum, sekum, dan kolon) diukur panjangnya.

Perhitungan Persentase Bobot dan Panjang Relatif Saluran Pencernaan

Pengukuran bobot organ dalam dilakukan dengan menimbang organ dalam tersebut per bagian dan dihitung persentasenya dengan rumus berikut:

$$
\begin{aligned}
& \% \text { bobot organ dalam }=\frac{\text { organ dalam }(\text { gram })}{\text { bobot hidup }(\text { gram })} \times 100 \% \\
& \text { Panjang organ relatif }=\frac{\text { panjang organ }(\mathrm{cm})}{\text { bobot hidup }(\text { gram })} \times 100 \\
& \text { (cm 100gram } \left.{ }^{-1}\right)
\end{aligned}
$$

\section{Rancangan Penelitian dan Analisis Data}

Perlakuan yang diberikan terdiri atas 2 perlakukan dengan perbedaan jenis mineral $\mathrm{Zn}$ dan $\mathrm{Cu}$ yang diberikan sebagai suplemen mineral di dalam ransum broiler (Tabel 2) yaitu:

T1: Mineral inorganik (CuSO4 dan $\mathrm{ZnSO} 4$ )

T2: Mineral organik (Intellibond $\mathrm{Cu}$ atau IBC dan Intelleibond $\mathrm{Zn}$ atau IBZ) 
Rancangan yang digunakan pada penelitian ini adalah Rancangan Acak Lengkap 2 perlakuan dengan 17 ulangan. Data dianalisis menggunakan IBM SPSS Statistic 22 dengan analisis uji T.

\section{Peubah yang Diamati}

Peubah yang diamati adalah persentasi bobot dari proventrikulus, gizzards, lemak abdomen, hati, empedu, limfa, tyhmus, bursa fabricius, ginjal, jantung, pankreas, serta persentase dan panjang duodenum, jejenum, ileum, sekum, dan kolon pada ayam broiler umur 35 hari.

\section{HASIL DAN PEMBAHASAN}

\section{Kondisi Umum Lingkungan Kandang}

Suhu nyaman termasuk dalam kategori zona suhu netral. Suhu lingkungan yang optimal akan meningkatkan performa dan mengurangi tingkat stress pada broiler. Suhu lingkungan yang tinggi, radiasi matahari yang tinggi secara langsung maupun tidak langsung dan kelembaban merupakan faktor utama stress lingkungan yang memberikan cekaman kepada ayam broiler (Etim et al. 2014). Menurut hasil penelitian yang dilakukan oleh Charoen Pokpand (2005) menyatakan bahwa suhu optimum untuk pertumbuhan broiler berturut-turut berdasarkan umur pemeliharaan adalah 1 hingga 3 hari $32^{\circ} \mathrm{C}$, umur 4 hingga 6 hari $31^{\circ} \mathrm{C}$, umur 7 hingga 14 hari $30^{\circ} \mathrm{C}$, umur 15 hingga 21 hari $28^{\circ} \mathrm{C}$, umur 22 hingga 35 hari $26^{\circ} \mathrm{C}$ dengan kelembaban relatif $60 \%$.

Rata-rata temperatur dan kelembaban relatif pada saat penelitian dapat dilihat pada Gambar 1. Suhu kandang pada saat pagi hari berkisar antara 24,04 oC hingga 31,45 oC dengan kelembaban relatif 59,50\% hingga $77 \%$. Suhu kandang pada siang hari mengalami kenaikan yaitu berkisar antara 32,07oC hingga 34,18 oC dengan kelembaban relatif $47 \%$ hingga 52,57\%. Suhu kandang pada sore hari mengalami penurunan kembali yaitu berkisar antara $28,39^{\circ} \mathrm{C}$ hingga $33,14^{\circ} \mathrm{C}$ dengan kelembaban relatif $52,38 \%$ hingga $64,50 \%$. Zona nyaman untuk broiler terjadi pada sore hari dimana suhu dan kelembaban berada pada keadaan yang optimum menurut Charoen Pokpand (2005). Kelembaban pada pagi hari terlalu tinggi dan suhu pada siang hari terlalu panas sehingga broiler tidak berada di dalam suhu nyaman.

Penurunan suhu dari minggu pertama hingga minggu kelima dikarenakan pengaruh cuaca yang memasuki pergantian musim dimana minggu pertama adalah musim pancaroba yang jarang sekali terjadi hujan dan minggu kelima adalah awal musim penghujan yang setiap hari selalu turun hujan sepanjang hari.

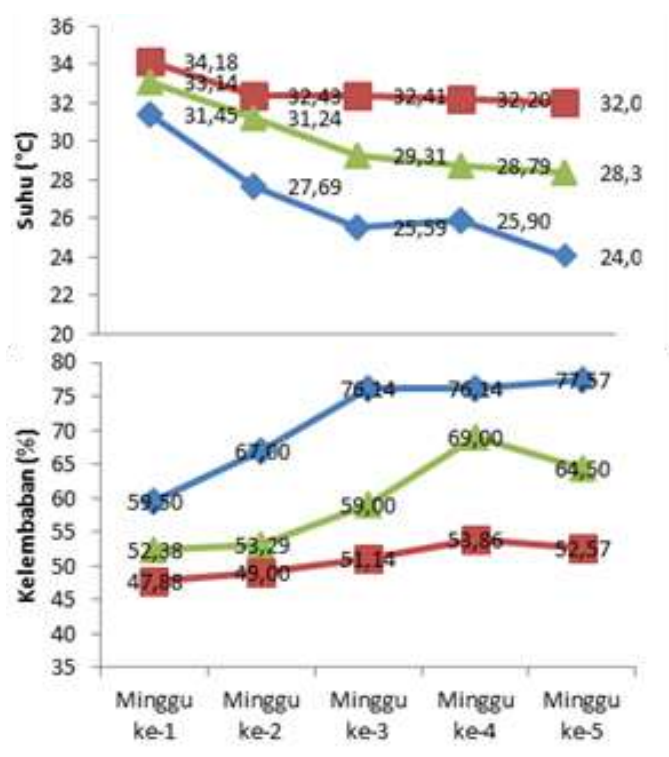

Gambar 1 Suhu dan kelembaban kandang pada pagi $(\bullet)$, siang $(\varpi)$, dan sore $(A)$ hari

Data pada Gambar 1 memperlihatkan fluktuasi suhu kandang dengan titik paling rendah pagi hari dan paling tinggi siang hari kemudian turun lagi pada sore hari. Fluktuasi suhu ini sangat mempengaruhi homeostasis tubuh broiler dalam menyeimbangkan suhu tubuh terhadap respon suhu lingkungan. Suhu lingkungan yang rendah dibutuhkan broiler untuk melepaskan panas dalam tubuh akibat metabolisme yang terjadi pada tubuh broiler. Laju metabolisme akan semakin meningkat dengan bertambahnya umur broiler sehingga meningkatkan panas yang dihasilkan oleh tubuh. Proses penglepasan panas tubuh ini adalah upaya untuk menyeimbangkan suhu tubuh dan lingkungan melalui evaporasi (panting) sehingga performa broiler tidak terganggu karena adanya stress panas.

\section{Organ Imunitas}

Sistem kekebalan tubuh broiler dapat berupa sistem kekebalan non spesifik (alami) dan sistem kekebalan spesifik (adaptif). Sistem kekebalan non spesifik merupakan sistem kekebalan secara alami diperoleh tubuh dan proteksi yang diberikan tidak terlalu kuat. Seluruh agen penyakit yang masuk ke dalam tubuh akan dihancurkan oleh sistem kekebalan tubuh tersebut sehingga proteksi yang diberikan tidak spesifik terhadap penyakit tertentu. Sistem kekebalan spesifik terdiri atas sistem berperantara sel (cell mediated immunity) dan sistem kekebalan berperantara antibodi. Bobot dan persentasi bobot organ imunitas disajikan pada Tabel 3 .

Organ imunitas terdiri atas organ imunitas primer (bursa fabricius dan thymus) dan organ imunitas sekunder (limfa). Perbedaan jenis mineral yang diberikan tidak mempengaruhi bobot dan persentase bobot bursa fabricius dan limfa seperti yang dapat dilihat pada Tabel 3. Persentase bobot thymus dipengaruhi oleh 
Tabel 3 Bobot dan persentase bobot organ imunitas pada broiler umur 35 hari

\begin{tabular}{lccc}
\hline \multirow{2}{*}{ Peubah } & \multicolumn{2}{c}{ Perlakuan } \\
\cline { 3 - 4 } & & $\mathrm{T} 1$ & $\mathrm{~T} 2$ \\
\hline Bobot Badan & (gram) & $1548,61 \pm 100,95$ & $1467,80 \pm 67,71$ \\
Bursa & (gram) & $0,80 \pm 0,20$ & $0,98 \pm 0,55$ \\
Fabricius & $(\%)$ & $0,05 \pm 0,01$ & $0,07 \pm 0,03$ \\
Limfa & (gram) & $2,08 \pm 0,50$ & $2,21 \pm 0,55$ \\
& $(\%)$ & $0,13 \pm 0,03$ & $0,15 \pm 0,04$ \\
Thymus & (gram) & $1,61 \pm 1,70$ & $2,17 \pm 0,68$ \\
& $(\%)$ & $0,11 \pm 0,05^{\mathrm{b}}$ & $0,15 \pm 0,03^{\mathrm{a}}$ \\
\hline
\end{tabular}

T1: Mineral inorganik (CuSO4 dan $\mathrm{ZnSO4)}$

T2: Mineral organik (Intellibond $\mathrm{Cu}$ atau IBC dan Intellibond Zn atau IBZ)

jenis mineral yang diberikan $(\mathrm{p}<0,05)$ walaupun bobot thymus tidak berbeda antar kedua perlakuan. Persentase bobot organ imunitas ini masih berada dibawah kisaran bobot normal bursa yaitu 0,19\%-0,22\% (Cazaban et al. 2015), limfa yaitu 0,18-0,23\% (Putnam 1991), dan thymus yaitu bawah $0,18 \%-0,23 \%$ (Sturkie 2000). Bobot dan persentase bobot organ yang masih di bawah kisaran normal mengindikasikan broiler masih mengalami cekaman panas yang menyebabkan terjadinya pelepasan hormon kortikosteron ke dalam pembuluh darah untuk membantu metabolisme ayam broiler. Hormon kortikosteron menyebabkan kegagalan sel mediasi dan kekebalan humoral karena perubahan konsentrasi limfoid yang dapat menurunkan bobot thymus, limfa, dan bursa fabricius (Aengwanich et al. 2003).

Thymus memiliki fungsi yang sama dengan bursa dan limfa yaitu sebagai organ imunitas yang melindungi tubuh broiler. Persentase thymus pada broiler yang diberikan mineral organik (T2) yang sedikit lebih besar menandakan bahwa mineral organik memiliki kemampuan lebih untuk mempertahankan kondisi tubuh dari cekaman panas. Semakin kecil ukuran thymus mengindikasikan semakin besar stress yang dialami oleh ayam broiler tersebut.

\section{Organ Dalam dan Lemak Abdomen}

Bobot dan persentase bobot organ dalam merupakan representasi dampak dari pakan yang dikonsumsi oleh ayam broiler. Bobot dan persentase bobot organ dalam dan lemak abdomen yang diperoleh pada penelitian ini disajikan pada Tabel 4.

Perbedaan jenis mineral yang diberikan (organik dan inorganik) tidak mempengaruhi bobot dan persentase bobot pada organ jantung, empedu, ginjal, dan lemak abdomen ayam broiler. Perbedaan jenis mineral yang diberikan (organik dan inorganik) tidak mempengaruhi bobot pada hati, proventrikulus, pankreas, dan gizzard tetapi memberikan pengaruh yang nyata pada persentase bobotnya $(p<0,05)$ seperti yang disajikan pada Tabel 4. Persentase bobot jantung dan empedu masih berada dalam kisaran normal yaitu 0,42\%-0,70\% (Putnam 1991) dan 0,11\%-0,12\% (Joo et al. 2013), tetapi
Tabel 4 Bobot dan presentase bobot organ dalam dan lemak abdomen ayam broiler umur 35 hari

\begin{tabular}{lccc}
\hline \multirow{2}{*}{ Peubah } & & \multicolumn{2}{c}{ Perlakuan } \\
\cline { 3 - 4 } Hati & $(\mathrm{gram})$ & $39,66 \pm 3,68$ & $33,81 \pm 2,11$ \\
& $(\%)$ & $2,57 \pm 0,19^{\mathrm{a}}$ & $2,31 \pm 0,11^{\mathrm{b}}$ \\
Jantung & $(\mathrm{gram})$ & $7,63 \pm 1,50$ & $7,10 \pm 0,93$ \\
& $(\%)$ & $0,50 \pm 0,08$ & $0,48 \pm 0,07$ \\
Empedu & $(\mathrm{gram})$ & $1,23 \pm 0,43$ & $1,33 \pm 0,37$ \\
& $(\%)$ & $0,08 \pm 0,03$ & $0,09 \pm 0,03$ \\
Ginjal & $(\mathrm{gram})$ & $8,99 \pm 2,40$ & $8,88 \pm 1,91$ \\
& $(\%)$ & $0,58 \pm 0,10$ & $0,61 \pm 0,05$ \\
Lemak & $($ gram) & $13,08 \pm 3,36$ & $13,18 \pm 2,31$ \\
Abdomen & $(\%)$ & $0,84 \pm 0,17$ & $0,88 \pm 0,16$ \\
Proventrikulus & $(\mathrm{gram})$ & $8,95 \pm 1,27$ & $9,06 \pm 0,98$ \\
& $(\%)$ & $0,59 \pm 0,06^{\mathrm{a}}$ & $0,55 \pm 0,03^{\mathrm{b}}$ \\
Pankreas & $(\mathrm{gram})$ & $4,03 \pm 6,39$ & $4,22 \pm 4,98$ \\
& $(\%)$ & $0,26 \pm 0,04^{\mathrm{b}}$ & $0,29 \pm 0,03^{\mathrm{a}}$ \\
Gizzard & $($ gram) & $22,88 \pm 1,63$ & $24,06 \pm 1,62$ \\
& $(\%)$ & $1,49 \pm 0,22^{\mathrm{b}}$ & $1,65 \pm 0,16^{\mathrm{a}}$ \\
\hline
\end{tabular}

persentase bobot ginjal berada di atas kisaran normal menurut Nickel et al. (1977) yaitu 0,21\%-0,28\% dan persentase lemak abdomen berada di bawah kisaran normal menurut Leenstra et al. (1986) yaitu 2,0\%-2,6\%. Persentase bobot hati ayam broiler yang diberikan mineral mikro organik (T2) lebih rendah dibandingkan dengan yang diberikan mineral mikro inorganik $(\mathrm{p}<0,05)$. Persentase bobot hati masih dalam kisaran normal menurut Putnam (1991) yaitu 1,7\%-2,8\%. Hati merupakan salah satu organ yang dapat mengindikasikan kesehatan ternak. Persentase bobot hati yang lebih rendah pada ayam broiler T2 mengindikasikan bahwa kinerja hati ayam broiler T2 lebih ringan dalam menetralisir racun yang masuk ke dalam hati. Hal ini diduga karena tingginya sifat bioavalibilitas mineral organik yang terakumulasi di hati (Luo et al. 2005) sehingga memaksimalkan kinerja hati untuk memelihara sistem imun (Feng et al. 2010). Pernyataan ini sejalan dengan persentase bobot ginjal yang berada di atas kisaran normal yang mengindikasikan bahwa meningkatnya kinerja ginjal untuk mengsekresikan sisa metabolisme akibat laju metabolisme yang sangat cepat akibat cekaman panas.

Persentase bobot proventrikulus ayam broiler yang diberikan mineral mikro organik (T2) lebih rendah dibandingkan dengan yang diberikan mineral mikro inorganik $(p<0,05)$. Persentase bobot proventrikulus masih berada dalam kisaran normal menurut Gabriella (2012) yaitu 0,43\%-0,59\%. Persentase bobot proventrikulus yang rendah pada $\mathrm{T} 2$ karena mineral organik $\mathrm{Zn}$ dan $\mathrm{Cu}$ memiliki sifat yang lebih sinergis mengakibatkan kinerja proventrikulus tidak terlalu berat untuk mengsekresikan asam hidrochloric.

Persentase bobot pankreas ayam broiler yang diberikan mineral mikro organik (T2) lebih tinggi dibandingkan dengan yang diberikan mineral mikro 
inorganik $(\mathrm{p}<0,05)$. Persentase bobot pankreas masih berada dalam kisaran normal menurut Gabriella (2012) yaitu $0,14 \%-0,35 \%$. Persentase bobot pankreas pada T2 yang lebih tinggi mengindikasikan bahwa mineral organik mampu meningkatkan konsentrasi enzim pada sekresi pankreas karena sifat bioavalibilitasnya yang tinggi.

Unggas tidak memiliki gigi sehingga gizzard memiliki fungsi sebagai penggiling. Fungsi utama dari gizzard adalah untuk menggiling partikel pakan menjadi ukuran yang lebih kecil sebelum memasuki duodenumdan bagian usus lainnya (Larsson 2016). Persentase bobot gizzard ayam broiler yang diberikan mineral mikro organik (T2) lebih tinggi dibandingkan dengan yang diberikan mineral mikro inorganik $(p<0,05)$. Persentase bobot gizzard masih berada dalam kisaran normal menurut Sturkie (2000) yaitu 1,6\%-2,3\%. Persentase bobot gizzard yang lebih tinggi pada T2 diduga dipengaruhi oleh bentuk pakan karena sifat dari gizzard yang bekerja secara mekanis.

\section{Saluran Pencernaan}

Usus terbagi menjadi dua jenis, yaitu usus halus dan usus besar. Usus halus terdiri dari tiga bagian yaitu duodenum, jejenum, dan illeum (Sturkie 2000). Usus halus merupakan tempat terjadinya penyerapan makanan. Usus besar (kolon) merupakan tempat terjadinya proses penyerapan air (Suryani 2014). Panjang dan persentase bobot usus disajikan pada Tabel 5.

Perbedaan jenis mineral yang diberikan (organik dan inorganik) tidak mempengaruhi panjang dan persentase bobot pada ileum ayam broiler. Perbedaan jenis mineral yang diberikan (organik dan inorganik) memberikan pengaruh yang nyata pada pada panjang dan persentase bobot duodenum dan jejenum $(\mathrm{p}<0,05)$ seperti yang disajikan pada Tabel 5. Tingkat absorpsi mineral ditentukan oleh interaksi antar mineral yang saling bersinergis atau antagonis.

Tabel 5 Panjang dan presentase bobot usus ayam broiler umur 35 hari

\begin{tabular}{|c|c|c|c|}
\hline \multirow{2}{*}{\multicolumn{2}{|c|}{ Peubah }} & \multicolumn{2}{|c|}{ Perlakuan } \\
\hline & & \multirow{2}{*}{$\frac{T 1}{2,09 \pm 0,21^{b}}$} & \multirow{2}{*}{$\frac{\mathrm{T} 2}{2,28 \pm 0,15^{\circ}}$} \\
\hline Duodenum & $\left(\mathrm{cm} \mathrm{100g^{-1 } )}\right.$ & & \\
\hline & (\%) & $0,59 \pm 0,09^{b}$ & $0,65 \pm 0,07^{a}$ \\
\hline \multirow[t]{2}{*}{ Jejunum } & $\left(\mathrm{cm} \mathrm{100g^{-1 } )}\right.$ & $5,30 \pm 0,36^{b}$ & $5,70 \pm 0,30^{a}$ \\
\hline & (\%) & $1,27 \pm 0,14^{b}$ & $1,40 \pm 0,18^{a}$ \\
\hline \multirow[t]{2}{*}{ Ileum } & $\left(\mathrm{cm} 100 \mathrm{~g}^{-1}\right)$ & $5,63 \pm 0,48$ & $5,84 \pm 0,46$ \\
\hline & (\%) & $1,12 \pm 0,13$ & $1,19 \pm 0,13$ \\
\hline \multirow[t]{2}{*}{ Sekum } & $\left(\mathrm{cm} \mathrm{100g^{-1 } )}\right.$ & $2,40 \pm 0,19^{b}$ & $2,56 \pm 0,15^{a}$ \\
\hline & (\%) & $0,44 \pm 0,19$ & $0,41 \pm 0,04$ \\
\hline \multirow[t]{2}{*}{ Kolon } & $\left(\mathrm{cm} \mathrm{100g^{-1 } )}\right.$ & $0,64 \pm 0,06$ & $0,67 \pm 0,06$ \\
\hline & (\%) & $0,92 \pm 0,26^{a}$ & $0,15 \pm 0,03^{b}$ \\
\hline
\end{tabular}

Mineral $\mathrm{Zn}$ dan $\mathrm{Cu}$ dalam bentuk inorganik bersifat antagonis, sedangkan mineral $\mathrm{Zn}$ dan $\mathrm{Cu}$ dalam bentuk organik memiliki sifat yang lebih sinergis (Ao et al. 2009). Sifat antagonis pada mineral organik menyebabkan penurunan daya serap yang mengakibatkan kedua mineral ( $\mathrm{Zn}$ dan $\mathrm{Cu}$ ) saling berkompetisi dalam mengikat ligand dan penyerapan mineral di mukosa usus. Produk mineral organik yang digunakan pada penelitian ini (IBZ® dan IBC®) adalah produk hydroxyclorides. Produk hydroxyclorides bersifat solubel pada $\mathrm{pH}$ rendah di lambung dan usus halus sehingga memiliki daya serap serta bioavalibilitas yang lebih tinggi pada unggas (Sadoval et al. 1999).

Sekum merupakan saluran pencernaan yang berfungsi sebagai tempat pencernaan secara mikrobial untuk mencerna nutrien yang tidak terserap oleh usus. Perbedaan jenis mineral yang diberikan (organik dan inorganik) tidak mempengaruhi persentase bobot pada sekumtetapi memberikan pengaruh yang nyata pada panjangnya $(p<0,05)$. Peningkatan persentase bobot sekum disebabkan peningkatan aktivitas pencernaan nutrisi yang tidak terserap di usus halus sebagai dampak berkurangnya kecernaan pakan di usus (Sharifi et al. 2012).

Perbedaan jenis mineral yang diberikan (organik dan inorganik) tidak mempengaruhi panjang kolon tetapi memberikan pengaruh yang nyata pada persentase bobotnya $(\mathrm{p}<0.05)$. Persentase bobot dan panjang kolon berada di atas kisaran normal menurut Suryani (2014) yaitu $0,60 \%-0,84 \%$ untuk persentase bobot dan $0,14 \mathrm{~cm}$

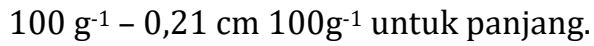

Hal ini mengindikasikan bahwa terjadi gangguan pada proses pencernaan yang menyebabkan kolon harus bekerja ekstra untuk menyerap air baik pada ayam broiler T1 maupun T2. Persentase bobot kolon T1 yang lebih tinggi diduga karena akumulasi ekskreta akibat tidak terserapnya nutrien dengan baik di usus halus sehingga kolon bekerja lebih keras dan terjadi penebalan dinding kolon.

\section{SIMPULAN}

Suplementasi mineral organik $\mathrm{Cu}$ dan $\mathrm{Zn}$ memiliki respon yang lebih baik dibanding mineral inorganik terhadap kesehatan ayam broiler dalam menghadapi stress akibat cekaman panas pada organ timus, hati, proventrikulus, pankreas, gizzard, duodenum, jejunum, ileum, sekum dan kolon.

\section{DAFTAR PUSTAKA}

Abdallah, AG, El-husseinny OM \& Abdel-Latif KO. 2009. Influence of some dietary organic mineral supplementations on broiler performance. International Journal of Poultry Science. 8: 291-298. 
Aengwanich W, Chuachan U, Phasuk Y, Vongpralab T, Pakdee P, Katavetin S, \& Simaraks S. 2003. Effect of ascorbic acid on respiratory rate, body temperature, heterophil:lymphocyte ratio and microscopic lesion score in lung, liver, kidney, cardiac muscle and spleen in broilers under chronic heat stress. Thai Journal of Agricultural Science. 36: 207-218.

Aksu D, Aksu T \& Onel SE. 2012. Does inclusion at low levels of organically complexed minerals versus inorganic forms create a weakness in performance or antioxidant defence system in broiler diets. International Journal of Poultry Science. 11: 666-672.

Ao T, Pierce JL, Power R, Dawson KA, Pescatore AJ, Cantor AH, \& Ford MJ. 2006. Evaluation of bioplex $\mathrm{Zn} \AA$ as organic zinc source for chicks. International Journal of Poultry Science. 5: 808-811.

Bao YM \& Choct M. 2009. Trace mineral nutrition for broiler chickens and prospect of applicatio of organically complexed trace minerals: a review. Journal of Animal Production Science. 49:269-282.

Bun S, Guo Y, Guo F, Ji F \& Cao H. 2011. Influence of organic zinc supplementation on the antioxidant status and immune responses of broilers challenged with Eimeria Tenella. Poultry Science. 90:1220-1226.

Cazaban C, Masferrer NM, Pascual R D, Espadamala M N, Costa T \& Gardin Y. 2015. Proposed bursa of fabricius weight to body weight ratio standard in commercial broilers. Journal of Poultry Science. 94: 2088-2093.

Charoen Pokphand Indonesia. 2006. Manual Broiler Manajemen CP 707. Jakarta (ID): Charoen Pokphand Indonesia

Dieck HT, Doring F, Roth HP \& Daniel H. 2003. Changes in rat hepatic gene expression in response to zinc deficiency as assessed by DNA arrays. Journal of Nutrition. 133: 1004-1010.

Etim NN \& Oguike MA. 2014. Environmental and management stressors: implications for reproductive and productive performances of farm animals in the tropics. Journal of Agriculture and Sustainability. 5(2):153-170.

Feng J, Ma W, Niu H, Wu X \& Wang Y. 2010. Effects of zinc glycine chelate on growth, hematological, and immunological characteristics in broilers. Biological Trace Element Research. 133: 203-211.

Gaetke LM \& Chow CK. 2003. Copper toxicity, oxidative, stress, and antioxidant nutrients. Journal of Toxicology 189: 147-163.

Joo YD, Kang CW, An BK, Ahn JS \& Borutova R. 2013. Effects of ochratoxin a and preventive action of a mycotoxin-deactivation product in broiler chickens. Veterinarija Ir Zootechnika. 61(83): 22 $-29$.

Larsson EC. 2016. The effect of Granite Grit on Broiler Chickens Performance and Gizzard Development [thesis]. Norwegia (NO): Norwegian University of Life Sciences.

Leenstra FR, Vereijken PFG \& Pit R. 1986. Fat deposition in broiler sire strain. I. Phenotypic and genetic variation in broiler and correlation between abdominal fat, body weight and feed convertion. Poultry Science. 65: 1225 - 1235.

Luo G, JI X, Lin F, Steward YX, Lu FA, Liu B \& Yu S. 2005. Effect of dietary supplementation with copper sulfate or tribasic copper chloride on broiler performance, relative copper bioavaibility, and oxidation stability of vitamin E in feed. Poultry Science. 84:88-93

Maltais D, Desroches D, Aouffen M, Mateescu MA, Wang R \& Paquin J. 2013. The blue copper ceruloplasmin induces aggregation of newly differentiated neurons: A potential modular of nervous system organization. Journal. of Neuroscience. 121: 73-82.

Nickel, R, Schummer, A \& Seiferle, E. 1977. Anatomy of The Domestic Birds. Berlin (DE): Verlag Paul Parey Publisher: CAB International
Powel SR. 2000. Antioxidant properties of zinc. Journal of Nutrition. 130: 1447S-1454S.

Putnam PA. 1991. Handbook of Animal Science. San Diego (US): Academic Press.

Sadoval M, Henry PR, Littell RC, Miles RD, Butcher GD \& Ammerman CB. 1999. Effect of dietary zinc source and method of oral administration on performance and tissue trace mineral concentration of broiler chicks. Journal of Animal Science. 77:17881799.

Sharifi SD, Shariatmadari F \& Yaghobfar A. 2012. Effects of inclusion of hull-less barley and enzyme supplementation of broiler diets on growth performance, nutrient digestion and dietary metabolisable energy content. Journal of Central European Agriculture. 13(1): 193-207

Sirri F, Maiorano G, Tavaniello S, Chen J, Petracci M \& Meluzzi A. 2016. Effect of different levels of dietary zinc, manganese, and copper from organic or inorganic sources on performance, bacterial chondronecrosis, intramuscullar collagen characteristics, and occurrence of meat quality defects of broiler chickens. Journal of Poultry Science. 95(8): 1813-1824.

Swiatkiewicz S, Arczewska WA \& Jozefiak D. 2014. The efficacy of organic minerals in poultry nutrition: A review and implications of recent studies. World Poultry Science Journal. 70: 475-486.

Star L. Klis JDVD, Rapp C \& Ward TL 2012. Bioavailability of organic and inorganic zinc sources in male broiler. Journal of Poultry Science. 91:3115-3120

Steel RGD \& Torrie JH. 1993. Prinsip dan Prosedur Statistika, Suatu Pendekatan Biometrik. Jakarta(ID): Gramedia Pustaka Utama.

Sturkie PD. 2000. Avian Physiology. Ed ke-15. New York (US): SpingerVerlag

Suryani L. 2014. Deteksi titer antibodi dan identifikasi faktor penyebab kegagalan vaksinasi terhadap Newcastle Disease pada ayam petelur di desa Bulo kabupaten Sidenreng Rappang. [skripsi]. Makassar (ID): Universitas Hasanuddin 